\title{
2. MAJOR AND TRACE ELEMENT GEOCHEMISTRY OF SEDIMENTS FROM EAST GREENLAND CONTINENTAL RISE: AN IMPLICATION FOR SEDIMENT PROVENANCE AND SOURCE AREA WEATHERING ${ }^{1}$
}

\author{
Saneatsu Saito ${ }^{2}$
}

\begin{abstract}
The bulk geochemistry of the nonbiogenic fraction of 70 samples from Ocean Drilling Program Site 918 in the Irminger Basin was determined by X-ray fluorescence. These data enabled the reconstruction of several aspects of Cenozoic paleoenvironmental evolution. By means of chemical stratigraphic analysis of the bulk sediments, seven major geochemical stages were identified and correlated with the significant lithologic units. The chemical compositions of the geochemical stages were basically controlled by differences in source area (volcanic/plutonic) and the degree of source area weathering. Important elements for characterizing source rock lithology are iron and sodium, whereas those for intensity of weathering are sodium, calcium, and potassium. The sodium-ferric iron ratio and potassium-calcium ratio provide useful indexes for the degree of the plutonic input and source area weathering, respectively.

Major chemical shifts occur at 550 meters below seafloor, which coincides with the beginning of ice-rafted debris (IRD) deposition in the upper Miocene. Mobile elements from weathering, such as calcium, manganese, and sodium, decrease downsection while immobile potassium increases. IRD is clearly distinguished from turbidites by its high content of the mobile elements. The chemical difference is explained by the difference between mechanical erosion by ice sheets and chemical weathering on land. Mechanical erosion by ice sheets does not involve source area chemical weathering and selective transportation by rivers. Turbidite materials were derived, however, from chemically weathered plutonic, metamorphic, and basaltic rocks on Greenland. Potassium in turbidites was recycled from basement rocks and paleosols, while sodium was removed during weathering and transportation.

The major Cenozoic paleoenvironmental changes in the East Greenland Margin are reconstructed from sediment compositions and geochemistry. Eocene sediments are derived from a weathered basaltic region. The upper Oligocene to lowermost Miocene is characterized by a weathered continental input. Fresh volcanic input began during the early Miocene. The supply of continental materials became dominant again during the middle Miocene, which coincides with the development of modern North Atlantic Deep Water. Unweathered IRD has been supplied since the late Miocene, which coincides with the first occurrence of dropstones.
\end{abstract}

\section{INTRODUCTION}

During Ocean Drilling Program (ODP) Leg 152, a 1200-m-thick sedimentary section ranging from the Eocene to Quaternary was drilled at Site 918 on the East Greenland Continental Rise. This was the first deep drilling conducted on the southeast Greenland Margin. These sediments give a detailed chronology of oceanographic and climatological events in the North Atlantic, including the discovery that glaciation began in southeast Greenland as early as $7 \mathrm{Ma}$ (Larsen et al., 1994), far earlier than previously thought (no older than late Pliocene: Shackleton et al., 1984; Funder, 1989). This glaciation was preceded by an influx of cold North Atlantic Deep Water (NADW) into the Irminger Basin during the middle Miocene (Larsen, Saunders, Clift, et al., 1994).

The aim of this study is to reconstruct paleoenvironmental conditions in the Irminger Basin during the Cenozoic by using bulk geochemical data from the nonbiogenic fraction of sediments. These analyses provide information about the provenance of the sediments relating to the history of volcanism, weathering, erosion, and sediment supply. These kinds of investigations have already been applied to a large number of Deep Sea Drilling Project and ODP sites. Paleoenvironmental studies in the northern Atlantic have been conducted using microfossil assemblages, isotopes, ice-rafted debris (IRD), heavy mineralogy, and clay mineralogy by ODP Legs 104, 151, 152, and 162 (Eldholm, Thiede, Taylor, et al., 1989; Myhre, Thiede, Firth,

${ }^{1}$ Saunders, A.D., Larsen, H.C., and Wise, S.W., Jr. (Eds.), 1998. Proc. ODP, Sci. Results, 152: College Station, TX (Ocean Drilling Program).

${ }^{2}$ Ocean Research Institute, University of Tokyo, 1-15-1 Minamidai, Nakano-ku, Tokyo 164, Japan. saito@ori.u-tokyo.ac.jp et al., 1995; Larsen, Saunders, Clift, et al., 1994). Although there are many clay mineralogical studies of terrigenous material to reconstruct paleoclimatology (e.g., Krissek, 1989; Froget et al., 1989; Holmes, this volume; Heiden and Holmes, this volume), only a few attempts to study the bulk geochemistry of sediments have been made. This study focuses on the bulk geochemistry of the nonbiogenic fraction of sediments to reveal changes in composition and to reconstruct environments in the provenance areas since Eocene time.

\section{ANALYTICAL METHODS AND MATERIALS}

Site 918 is particularly good for this type of study because shelf sites are too proximal to Greenland and Site 918 produced the best information on the timing of IRD. More than 70 samples of sand and sandy silt from Site 918 were analyzed with X-ray fluorescence (XRF). The sampling interval was approximately one sample per core. The samples were ground in an agate mortar to minimize contamination. Biogenic and detrital carbonate components were removed from these samples by treatment with $4 \mathrm{~mol} / \mathrm{L}$ of acetic acid for major element analysis. $\mathrm{H}_{2} \mathrm{O}^{-}$and loss on ignition (LOI) were determined by a gravimetric method. Fusion beads were prepared from $0.4 \pm 0.0002 \mathrm{~g}$ (dried at $950^{\circ} \mathrm{C}$ overnight) and $4 \pm 0.002 \mathrm{~g} \mathrm{Li}$-tetraborate for major element analysis. Pressed powder pellets were prepared from about $4 \mathrm{~g}$ with a vinyl chloride ring for trace element analysis. XRF analyses were performed with a Rigaku Model 3270 in the Ocean Research Institute, University of Tokyo. These analyses gave 10 major elements $\left(\mathrm{SiO}_{2}, \mathrm{TiO}_{2}, \mathrm{Al}_{2} \mathrm{O}_{3}, \mathrm{Fe}_{2} \mathrm{O}_{3}, \mathrm{MnO}, \mathrm{MgO}, \mathrm{CaO}\right.$, $\mathrm{Na}_{2} \mathrm{O}, \mathrm{K}_{2} \mathrm{O}$, and $\mathrm{P}_{2} \mathrm{O}_{5}$ ) and nine trace elements $(\mathrm{Rb}, \mathrm{Sr}, \mathrm{Zr}, \mathrm{Nb}, \mathrm{Y}, \mathrm{Th}$, $\mathrm{Pb}, \mathrm{Ni}$, and $\mathrm{Ba}$ ). Major element data are considered accurate between $1 \%$ and $5 \%$, whereas trace element accuracy varies from $2 \%$ to $10 \%$. 


\section{GENERAL LITHOSTRATIGRAPHY AND AGE CONTROL AT SITE 918}

Site 918 is located on the upper continental rise off Southeast Greenland (Fig. 1), and the 1200-m-thick sedimentary sequence recovered there is divided into five lithologic units overlying weathered basaltic basement (Fig. 2). The lithostratigraphy of Site 918 is described in detail by Larsen, Saunders, Clift, et al. (1994). The age assignments for this sequence are from Wei (this volume).

Lithologic Unit I (0-600.0 meters below seafloor [mbsf]) is an upper Miocene to Holocene dominantly dark gray silt, with volcanogenic and continental components. It is divided into five subunits on the basis of the presence of turbidites, the occurrence of a high concentration of IRD and dropstones, a decrease in the concentration of dropstones, and the absence of IRD and dropstones. Subunits IA, IB, IC, ID, and IE are composed of interbedded sand with silt and IRD, interbedded turbidites with silt and IRD, silt enriched in IRD, silt with IRD, and silt, respectively. Lithologic Unit II (600.0-806.5 mbsf) is composed of lower to upper Miocene nannofossil chalk and silt, moderately to heavily burrowed. Frequent micritic and glauconitic hardgrounds occur at the base and top of the unit. The silt beds contain a mixed suite of minerals such as quartz, feldspar, hornblende, and pyroxene derived from both volcanic and continental terranes. Lithologic Unit III (806.5-1108.2 mbsf) comprises upper Oligocene to lower Miocene sand, silt and nannofossil chalk, and is divided into two subunits. The upper Subunit IIIA comprises interbeds of thin, massive, or laminated sand beds with frequent silt and nannofossil chalk beds. The lower Subunit IIIB comprises massive, quartzrich turbidite sands, which are intermittently heavily bioturbated. Dolomite is a common constituent in Subunit IIIB, and there is an increase in the glauconitic component downcore. Lithologic Unit IV (1108.2-1157.9 mbsf) comprises middle Eocene interbeds of nannofossil chalk and volcaniclastic silt with nannofossils. Lithologic Unit V (1157.9-1189.4 mbsf) consists of lower Eocene glauconitic, volcaniclastic sandy silt with interbedded horizons of calcareous sand.

\section{RESULTS}

Analytical data of the major and trace elements are shown in the Appendix. Contents of major elements are plotted as a function of silica contents for all samples in Figure 3. Titanium, aluminum, ferric iron, magnesium, and phosphorus (on the left side in Fig. 3) show a clear decreasing trend as silica increases. Manganese, calcium, sodium, and potassium (on the right side in Fig. 3), however, show a nonlinear trend. The chemical variations imply that these four elements are sensitive to various paleoenvironmental factors. Diagenesis is a minor factor throughout the Site 918 sedimentary sequence (Larsen, Saunders, Clift, et al., 1994).

Depth profiles of the representative elements are shown in Figure 4. Titanium and ferric iron, which show a simple decreasing trend with increasing silica, basically show this reverse pattern through the Eocene to Holocene (Fig. 4). Profiles of elements such as manganese, calcium, sodium, and potassium (which have a nonlinear trend in Fig. 3) show specific trends with depth (Fig. 4). These trends are independent of the trend of silica content.

Seven geochemical stages are distinguished from the variation of the composition of the elements (Table 1). Important elements for geochemical stage classification are iron, calcium, sodium, and potassium. Basically, the chemical profile of potassium shows the opposite trend of calcium, and the profile of ferric iron shows the opposite trend of sodium (Fig. 4). Geochemical Stage 1 is characterized by a higher value of calcium and sodium and a lower value of potassium and ferric iron, whereas geochemical Stage 3 is characterized by a higher value of potassium, intermediate values of sodium and ferric iron, and a lower value of calcium. Geochemical Stages 1 and 3 are lithologically correlated to the IRD-rich marine silt and the marine silt without IRD, respectively. Geochemical Stage 2 is the transitional stage between geochemical Stages 1 and 3. Geochemical Stage 4 is characterized by higher values of calcium and ferric iron, and lower values of sodium and potassium, whereas geochemical Stage 6 is characterized by a higher value of potassium, an intermediate value of sodium, and lower values of calcium and ferric iron. Geochemical Stages 4 and 6 are lithologically correlated to the marine silt with volcaniclastics and the marine silt with turbidites, respectively. Geochemical Stage 5 is the transitional stage between geochemical Stages 4 and 6. Geochemical Stage 7, characterized by lower values of calcium and sodium and higher values of potassium and ferric iron, is due to the volcaniclastic sediments.

The stage boundaries generally coincide with lithologic unit boundaries, although some boundaries coincide with seismic unit boundaries. The geochemical boundaries are at about $300 \mathrm{mbsf}$ (lithologic Subunits IC/ID), $550 \mathrm{mbsf}$ (lithologic Subunits ID/IE), 650 mbsf (seismic Subunits 4A/4B), 770 mbsf (seismic Units 4/5), $1000 \mathrm{mbsf}$ (seismic Subunits 5A/5B), and $1100 \mathrm{mbsf}$ (lithologic Units III/IV).

Seismic unit boundaries between $4 \mathrm{~A}$ and $4 \mathrm{~B}, 4$ and 5 , and $5 \mathrm{~A}$ and $5 \mathrm{~B}$ are also correlated to significant lithologic boundaries (Larsen, Saunders, Clift, et al., 1994). The boundary between seismic Subunits $5 \mathrm{~A}$ and $5 \mathrm{~B}$ is correlated with the last occurrence of massive siliciclastic turbidites in lithologic Unit III. The boundary between seismic Units 4 and 5 is correlated with a rapid decrease of nannofossil chalk in the lower part of lithologic Unit II. The boundary between seismic Subunits $4 \mathrm{~A}$ and $4 \mathrm{~B}$ is correlated with a rapid decrease of nannofossil chalk in the upper part of lithologic Unit II. The most remarkable characteristic is that manganese, sodium, and calcium decrease downsection at about 550 mbsf, while potassium increases downsection. Trace elements such as rubidium, thorium, and lead show the same trend as potassium. This horizon is the most remarkable chemical shift from the Eocene through the Holocene.

\section{PROVENANCE INTERPRETATION BASED ON GEOCHEMISTRY}

Geochemical profiles of nonbiogenic fractions at Site 918 show several consistent compositional changes. The reconstruction of paleoenvironments on the basis of geochemical data requires a knowledge of the flux of volcanic, ice-rafted, and turbiditic materials. For this discussion, all possible origins and the significance of the sediments were considered in Larsen, Saunders, Clift, et al. (1994).

The abundance of sodium-rich feldspar is generally influenced by the composition of plutonic input (Vallier et al., this volume). Additionally, the variations of the contents of sodium and ferric iron show opposite trends throughout Site 918. Geochemical Stages 4 and 7 are characterized by low-Na and high-Fe due to a high degree of volcanic contribution rather than plutonic input (Vallier et al., this volume). Therefore, the depth profile of the sodium-ferric iron ratio can be treated as one of the indices for the degree of the plutonic input.

The value of the sodium-ferric iron ratio at Site 918 changes significantly due to geochemical stages (Fig. 5A). The trend is generally characterized by a higher value for Geochemical Stages 1 and 6 , a transitional value for Geochemical Stages 2 and 5, an intermediate value for Geochemical Stage 3, and a lower value for Geochemical Stages 4 and 7. The higher values in Geochemical Stages 1 and 6 coincide with the plutonic input by IRD and turbidites, respectively. The sediments in Geochemical Stage 3, the mixture of terrigenous and volcaniclastic components, show an intermediate value of sodium-ferric iron ratio. Geochemical Stages 4 and 7 , which is the volcaniclastic series, generally show a lower sodium-ferric iron ratio.

Sodium and calcium are typically mobile elements in weathering, whereas potassium is a relatively stable element in weathering and is typically added to sediments during transport and deposition. Therefore, sodium, calcium, and potassium are most useful in characteriz- 
A
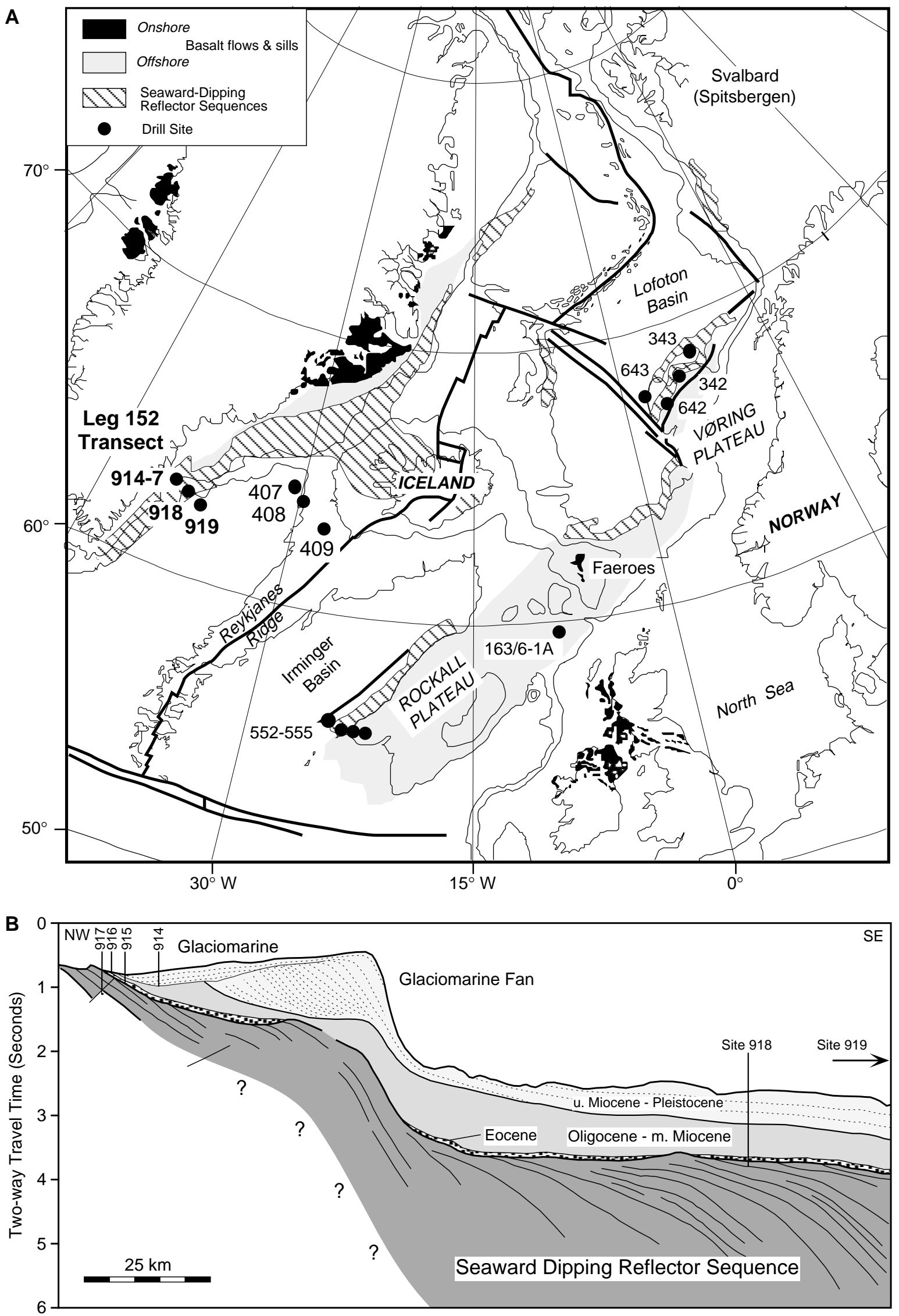

Figure 1. A. Map showing Leg 152 drill sites. B. Interpreted seismic section showing Leg 152 drill sites. 
Figure 2. Lithologic column of Site 918, showing lithologic units and seismic units. Lithologic Subunit IA: interbedded, soupy, fining-upward ferromagnesian-foraminifer sand with firmer silt, clay; IRD. Lithologic Subunit IB: interbedded green and brown turbidites with silt, \pm fossils and IRD. Lithologic Subunit IC: silt enriched in IRD (diamicton). Lithologic Subunit ID: silt with IRD. Lithologic Subunit IE: silt. Lithologic Unit II: nannofossil chalk, silt, silt with nannofossils, micritic hardgrounds. Lithologic Subunit IIIA: turbiditic sands interbedded with silt and nannofossil chalk. Lithologic Subunit IIIB: coarse, massive siliciclastic turbidites. Lithologic Unit IV: volcanic silt, nannofossil chalk. Lithologic Unit V: volcanic silt, clay, and glauconitic sandstone.

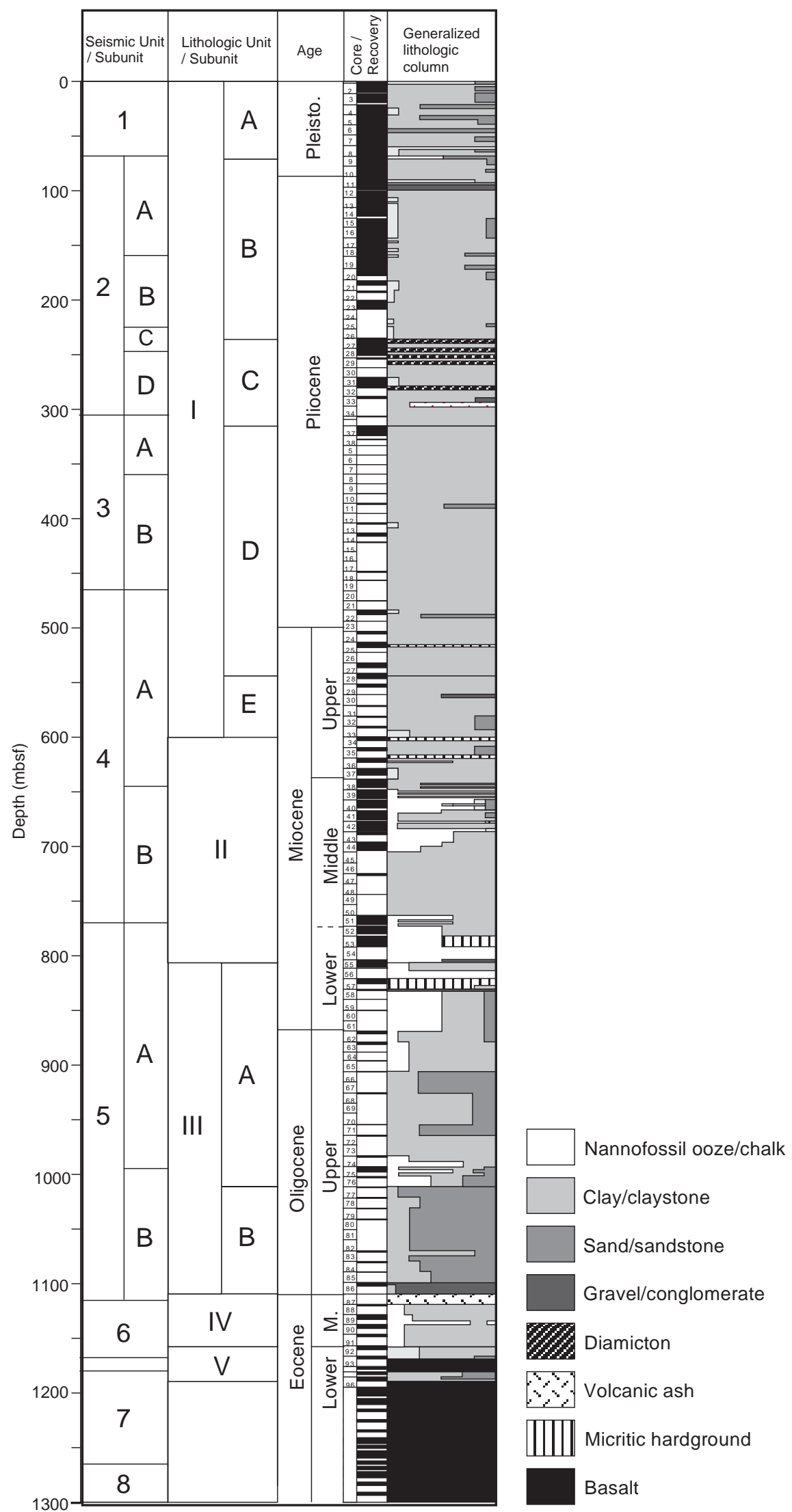



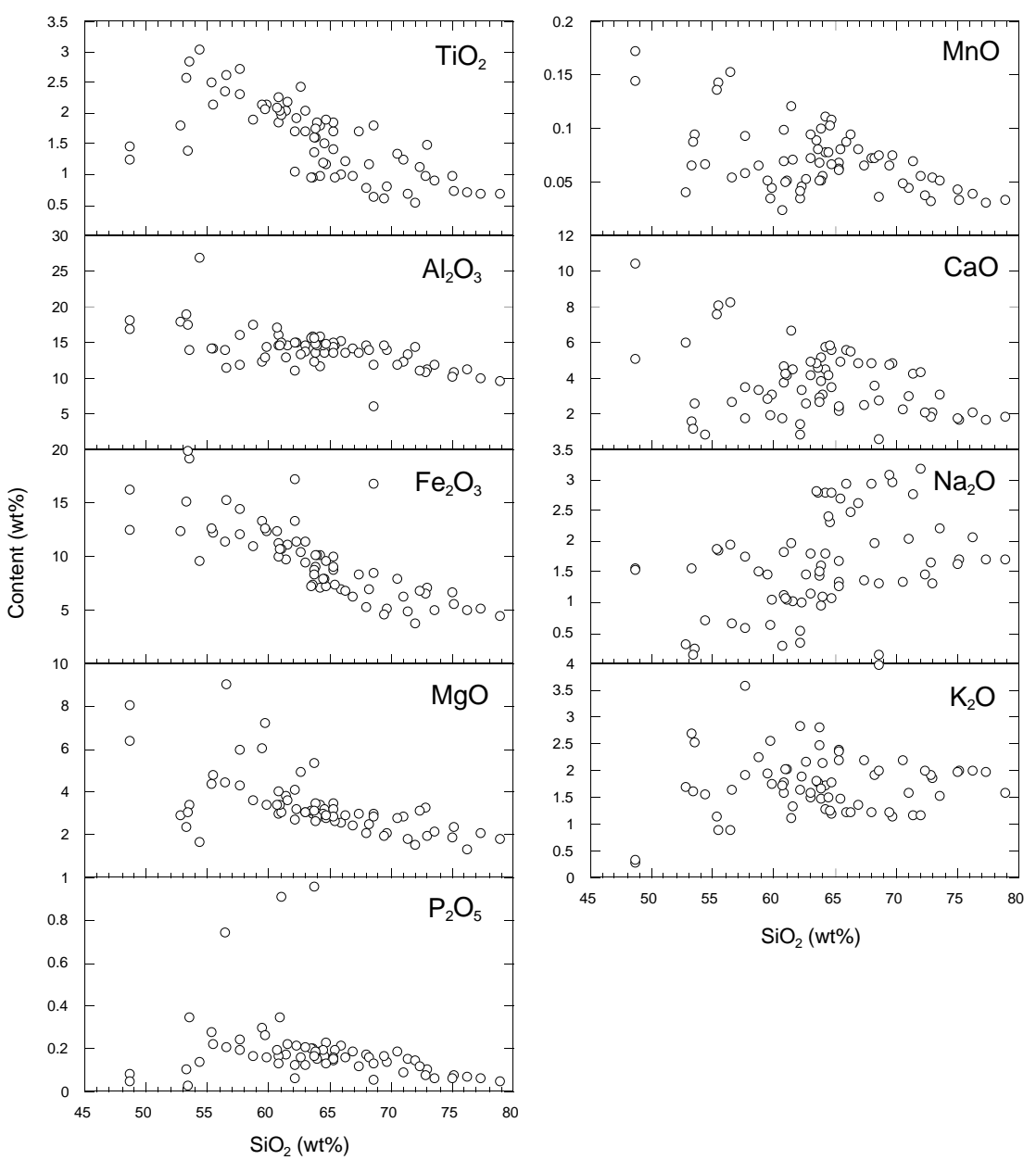

Figure 3. Variations in major elements content (wt\%) with increasing $\mathrm{SiO}_{2}(\mathrm{wt} \%)$.

ing the provenance of the sediments (Nesbitt and Young, 1982; Harnois, 1988). Potassium and calcium especially show opposite behavior throughout Site 918. The potassium-calcium ratio is one of the indices for the degree of weathering in addition to the CIA (chemical index of alteration; Nesbitt and Young, 1982). The potassium-calcium ratio at Site 918 changes significantly through the geochemical stages (Fig. 5B). The trend is generally characterized by a lower value for geochemical Stages 1 and 4, a transitional value for geochemical Stages 2 and 5, and higher values for geochemical Stages 3, 6, and 7 (which suggest a high degree of weathering). Sharply lower potassium-calcium ratios characterize the lowermost part of geochemical Stage 2 (corresponding to the horizon of oldest dropstones; Larsen et al., 1994) and sediments in geochemical Stages 1 and 2 (mainly composed of immature glaciomarine sediments with IRD). The sediments in geochemical Stage 3 (the mixture of turbidites and volcaniclastic components) show a higher potassium-calcium ratio. The beginning of the development of NADW is correlated with the occurrence of poorly sorted sand layers in the lowermost part of geochemical Stage 3 (Larsen, Saunders, Clift, et al., 1994). The sediments in geochemical Stage 4 (a mixture of volcaniclastic components and nannofossil chalk without turbidites) show a lower potassium-calcium ratio. Geochemical Stage 6 is the terrigenous turbidite series, which shows a higher potassium-calcium ratio. Geochemical Stage 7, the volcaniclastic series, generally shows a higher potassium-calcium ratio except for two samples.

Figure 6A shows the variation of the potassium-calcium ratio as a function of the sodium-ferric iron ratio for all samples. In this diagram, the sodium-ferric iron ratio of volcaniclastics is generally low.
Siliciclastic sediments show a high sodium-ferric iron ratio. The IRD and turbidites are clearly separated in this diagram. IRD is calciumrich, whereas turbidites are potassium-rich.

Figure $6 \mathrm{~B}$ shows the variation of the sodium-potassium ratio with increasing silica for all samples. In this diagram, the sodium-potassium ratio of volcaniclastic sediments is generally low and rapidly decreases with increasing silica. On the other hand, quartz-rich siliciclastic sediments show a high sodium-potassium ratio, and it increases with increasing silica content. Therefore, it is possible to distinguish nonvolcanic from volcaniclastic sediments. IRD and turbidites are clearly separated in this diagram. IRD is sodium-rich, whereas turbidites are potassium-rich.

The compositional differences between the IRD and turbidites are also supported by other data. Vallier et al. (this volume) discuss the compositional variation of heavy minerals from coarse fractions. Paleogene turbidites are mainly composed of plutonic minerals with volcanic and metamorphic minerals, whereas the IRD is a mixture of volcanic and plutonic components. The composition of dropstones suggests that the main volcanic component of the IRD is basalts from the North Atlantic Volcanic Province (Larsen, Saunders, Clift, et al., 1994). Basalt is the largest component $(33.2 \%)$ of the dropstones (Larsen, Saunders, Clift, et al., 1994). The large occurrence of basaltic fragments in the IRD above $550 \mathrm{mbsf}$ is one of the factors in the chemical differences, such as the enrichment of calcium and manganese.

The chemical differences between the IRD and turbidites are explained not only by the compositional difference but also by the sediment supply process. Ice-rafting does not involve source area weath- 

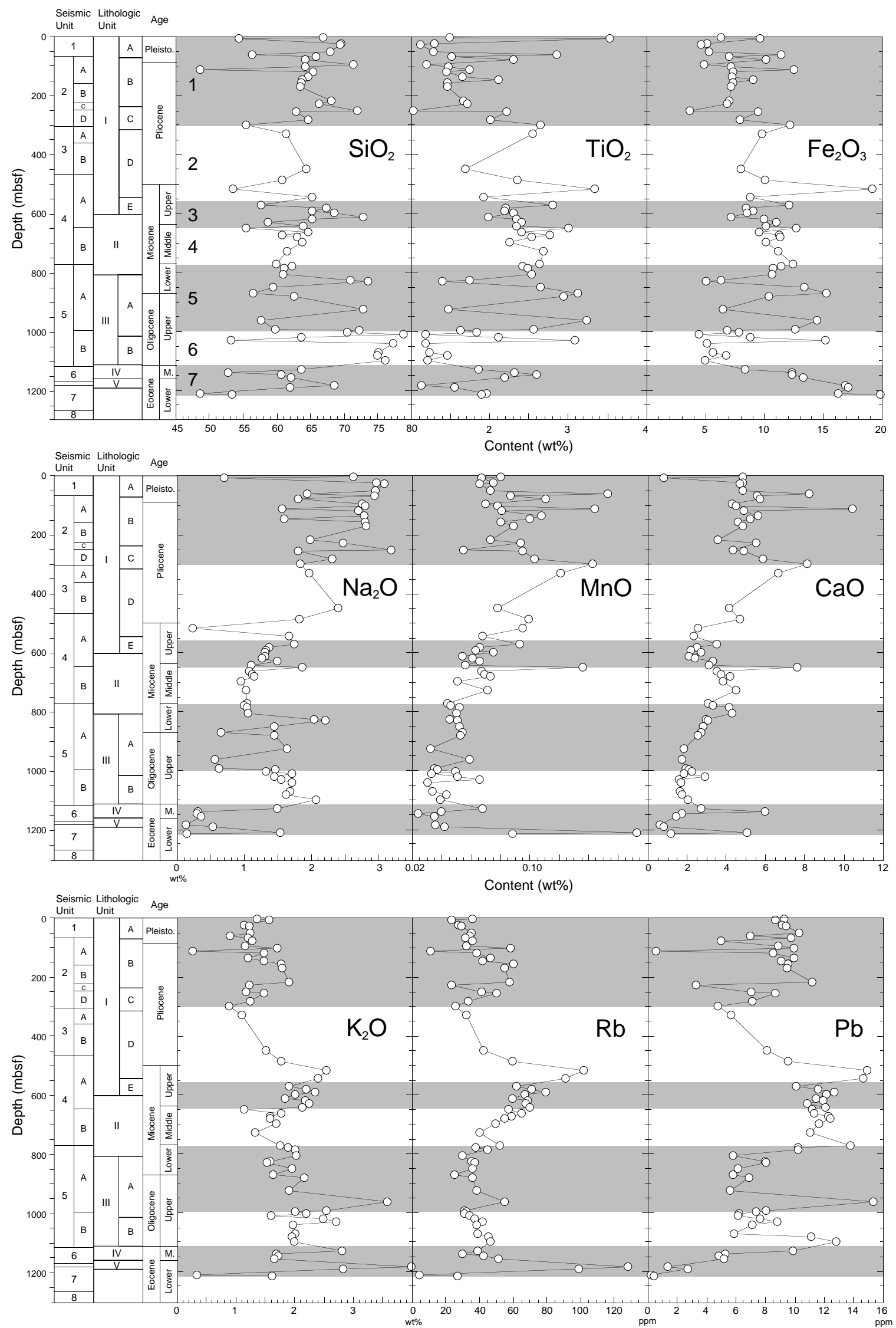

Figure 4. Variations in $\mathrm{SiO}_{2}, \mathrm{TiO}_{2}, \mathrm{Fe}_{2} \mathrm{O}_{3}, \mathrm{Na}_{2} \mathrm{O}, \mathrm{MnO}, \mathrm{CaO}$, and $\mathrm{K}_{2} \mathrm{O}$ content (wt\%) and $\mathrm{Rb}$ and $\mathrm{Pb}$ concentration (ppm) with depth, showing geochemical units. 
Table 1. Summary of geochemical stage classification and characteristics of sediment type.

\begin{tabular}{cccccccll}
\hline \multirow{2}{*}{$\begin{array}{c}\text { Geochemical } \\
\text { stages }\end{array}$} & $\begin{array}{c}\text { Depth } \\
\text { (mbsf) }\end{array}$ & Mn & $\mathrm{Ca}$ & $\mathrm{Na}$ & $\mathrm{K}$ & $\mathrm{Fe}$ & $\begin{array}{c}\text { Dominant } \\
\text { sediment type }\end{array}$ & \multicolumn{1}{c}{ Dominant source } \\
\cline { 3 - 6 } & $0-300$ & $\mathrm{H}$ & $\mathrm{H}$ & $\mathrm{H}$ & $\mathrm{L}$ & $\mathrm{L}$ & IRD & Fresh plutonic with volcanic \\
1 & $300-550$ & $\mathrm{~T}$ & $\mathrm{~T}$ & $\mathrm{~T}$ & $\mathrm{~T}$ & $\mathrm{~T}$ & IRD & Transitional \\
3 & $550-650$ & $\mathrm{M}$ & $\mathrm{L}$ & $\mathrm{M}$ & $\mathrm{H}$ & $\mathrm{M}$ & Turbidite & Weathered plutonic with volcanic \\
4 & $650-770$ & $\mathrm{M}$ & $\mathrm{H}$ & $\mathrm{L}$ & $\mathrm{L}$ & $\mathrm{H}$ & Volcaniclastic & $\begin{array}{l}\text { Fresh volcanic } \\
\text { Trean }\end{array}$ \\
5 & $770-1000$ & $\mathrm{~T}$ & $\mathrm{~T}$ & $\mathrm{~T}$ & $\mathrm{~T}$ & $\mathrm{~T}$ & Turbidite & Transitional \\
6 & $1000-1100$ & $\mathrm{~L}$ & $\mathrm{~L}$ & $\mathrm{M}$ & $\mathrm{H}$ & $\mathrm{L}$ & Turbidite & Weathered plutonic and metamorphic \\
7 & $1100-1220$ & $\mathrm{~L}$ & $\mathrm{~L}$ & $\mathrm{~L}$ & $\mathrm{H}$ & $\mathrm{H}$ & Volcaniclastic & Weathered volcanic \\
\hline
\end{tabular}

Notes: $\mathrm{H}=$ high contents, $\mathrm{M}=$ medium contents, $\mathrm{L}=$ low contents, $\mathrm{T}=$ transitional, and $\mathrm{IRD}=$ ice-rafted debris.

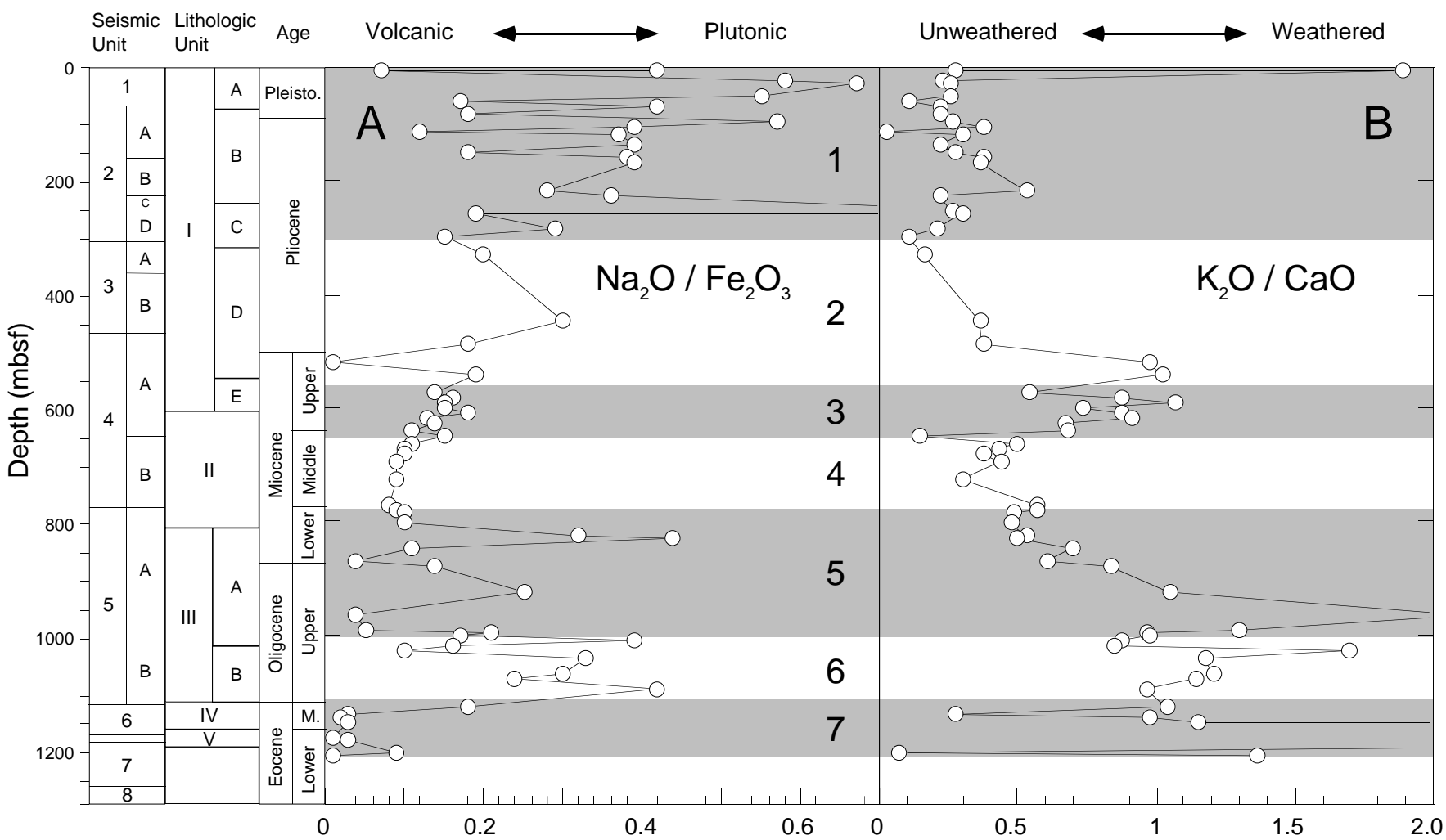

Figure 5. A. Variations in the $\mathrm{Na}_{2} \mathrm{O}-\mathrm{Fe}_{2} \mathrm{O}_{3}$ ratio with depth, showing geochemical unit boundaries. B. Variations in the $\mathrm{K}_{2} \mathrm{O}-\mathrm{CaO}$ ratio with depth, showing geochemical units.

ering and selective transportation by rivers. Elements mobilized by weathering, such as calcium, manganese, and sodium, are preserved in IRD during mechanical erosion by ice. On the contrary, the turbidite material was derived from weathered plutonic, metamorphic, and basaltic rocks with paleosols (Holmes, this volume).

The chemical compositions of the Paleogene volcaniclastic series (geochemical Stage 7) are different from those of the Neogene (geochemical Stage 4). Low contents of manganese, calcium, and sodium and high contents of aluminum and iron in the Paleogene volcaniclastic sediments strongly suggest subaerial weathering of basalts from the North Atlantic Volcanic Province. The Neogene volcaniclastics are unweathered and contain fresh volcanic glasses that may have originated from extrusive Icelandic eruptions (Clift et al., this volume).

\section{SUMMARY}

The sedimentary record at Site 918 of the East Greenland Continental Margin is a fascinating succession that furthers our under- standing of how geochemical and sedimentary data respond to paleoenvironmental change. This paper shows clearly how the bulk geochemistry of sediments can be used to characterize the distribution of both weathered components transported by turbidity currents and unweathered IRD. It can also be used to compare these distributions with the general evolutionary stages of the northern Atlantic region.

The sedimentary sequence at Site 918 is divided into seven geochemical stages using bulk geochemistry profiles, especially those of iron, manganese, calcium, sodium, and potassium. The stage boundaries are correlated with the significant lithologic boundaries. Provenances are divided into four types with respect to lithology and geochemistry (Table 1), namely weathered volcaniclastic sediments (Paleogene), fresh volcaniclastic sediments (Neogene), mature turbidites, and immature IRD. Differences in source areas (volcanic/ plutonic) and in erosional (mechanical/chemical) and transport processes mainly control the sediment chemistry.

IRD and turbidites are clearly separated using sodium, calcium, and potassium ratios. The chemical difference between IRD and turbidites is explained by the difference between mechanical erosion by 

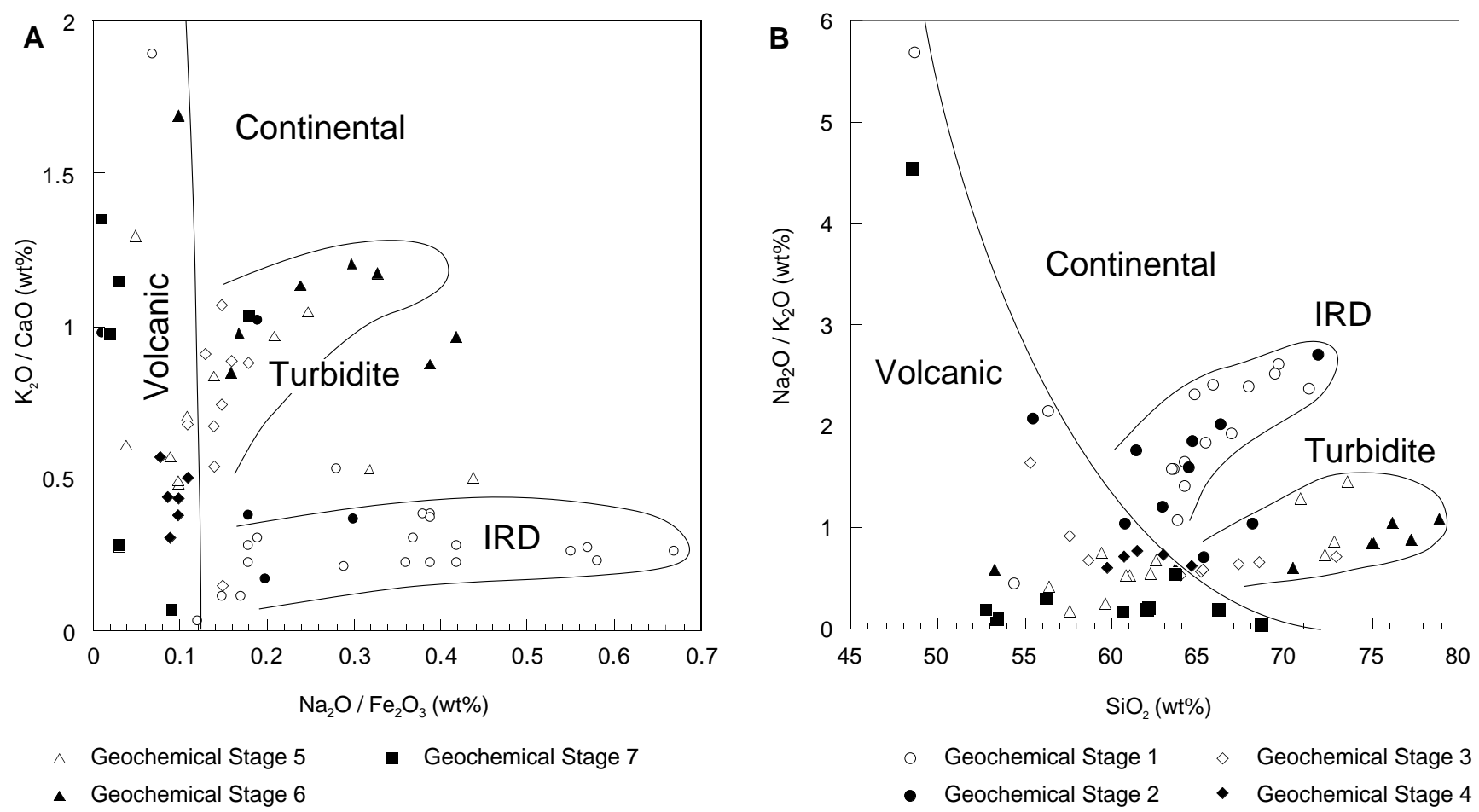

$\triangle$ Geochemical Stage 5
$\triangle \quad$ Geochemical Stage 6

- Geochemical Stage 1

- Geochemical Stage 2 $\diamond$ Geochemical Stage 3

- Geochemical Stage 4

Figure 6. A. Variations in the $\mathrm{K}_{2} \mathrm{O}-\mathrm{CaO}$ ratio as a function of the $\mathrm{Na}_{2} \mathrm{O}-\mathrm{Fe}_{2} \mathrm{O}_{3}$ ratio for all samples from Site 918, showing different fields between the IRD (icerafted debris) and turbidites. B. Variations in the $\mathrm{Na}_{2} \mathrm{O}-\mathrm{K}_{2} \mathrm{O}$ ratio with increasing $\mathrm{SiO}_{2}$ for all samples from Site 918 , showing different fields between the IRD and turbidites.

ice sheet and chemical weathering on land. The mechanical erosion preserves the mobile elements such as sodium and calcium. Potassium in turbidites was fixed or recycled from basement rocks with paleosols, whereas sodium was removed during weathering and transportation. The potassium-calcium and sodium-potassium ratios can be used to characterize the degree of weathering of the provenance region.

Figure 7 summarizes the sedimentary evolution of the East Greenland Margin. Eocene sediments are derived from a weathered basaltic region. The upper Oligocene to lowermost Oligocene is characterized by continental input. Volcanic input began during the early Miocene. Continental supply became dominant again during the middle $\mathrm{Mi}$ ocene, which coincides with the development of modern NADW. Major chemical shifts occurred at about $7 \mathrm{Ma}$, which coincides with the first occurrence of dropstones. Sodium, manganese, and calcium contents decrease downsection, whereas potassium contents increase at this point in the sequence.

\section{ACKNOWLEDGMENTS}

Discussions with Drs. T. Vallier and M.A. Holmes, as well as the onboard sedimentologists on Leg 152, helped me in preparing this chapter. I thank Dr. Y. Tatsumi of Kyoto University, Dr. T. Kogiso of Tokyo Institute of Technology, and Dr. T. Ishii of the Ocean Research Institute, University of Tokyo, for XRF analyses and for their valuable suggestions. I thank N. Sueda of the Ocean Research Institute, University of Tokyo, for making thin sections. I also thank the reviewers for many useful suggestions.

\section{REFERENCES}

Eldholm, O., Thiede, J., Taylor, E., et al., 1989. Proc. ODP, Sci. Results, 104: College Station, TX (Ocean Drilling Program).
Froget, C., Desprairies, A., Latouche, C., and Maillet, N., 1989. Paleoenvironmental significance of Cenozoic clay deposits from the Norwegian Sea: ODP Leg 104. In Eldholm, O., Thiede, J., Taylor, E., et al., Proc. ODP, Sci. Results, 104: College Station, TX (Ocean Drilling Program), 41-60.

Funder, S., 1989. Development of climate, glaciation and ocean circulation. In Fulton, R. (Ed.), Quaternary Geology of Canada and Greenland. Geol. Soc. Am., Geol. of North Am. Ser., K-1:783-792.

Harnois, L., 1988. The CIW index: a new chemical index of weathering. Sediment. Geol., 55:319-322.

Krissek, L.A., 1989. Bulk mineralogy of nonbiogenic sediments from ODP Sites 642 and 643, Norwegian Sea: implications for sediment provenance and recycling. In Eldholm, O., Thiede, J., Taylor, E., et al., Proc. ODP, Sci. Results, 104: College Station, TX (Ocean Drilling Program), 29-39.

Larsen, H.C., Saunders, A.D., Clift, P.D., et al., 1994. Proc. ODP, Init. Repts., 152: College Station, TX (Ocean Drilling Program).

Larsen, H.C., Saunders, A.D., Clift, P.D., Beget, J., Wei, W., Spezzaferri, S., and the ODP Leg 152 Scientific Party, 1994. Seven million years of glaciation in Greenland. Science, 264:952-955.

Myhre, A.M., Thiede, J., Firth, J.V., et al., 1995. Proc. ODP, Init. Repts., 151: College Station, TX (Ocean Drilling Program).

Nesbitt, H.W., and Young, G.M., 1982. Early Proterozoic climates and plate motions inferred from major element chemistry of lutites. Nature, 299:715-717.

Shackleton, N.J., Backman, J., Zimmerman, H., Kent, D.V., Hall, M.A., Roberts, D.G., Schnitker, D., Baldauf, J.G., Desprairies, A., Homrighausen, R., Huddlestun, P., Keene, J.B., Kaltenback, A.J., Krumsiek, K.A.O., Morton, A.C., Murray, J.W., and Westberg-Smith, J., 1984. Oxygen isotope calibration of the onset of ice-rafting and history of glaciation in the North Atlantic region. Nature, 307:620-623.

Date of initial receipt: 30 October 1995

Date of acceptance: 28 June 1996

Ms 152SR-207 

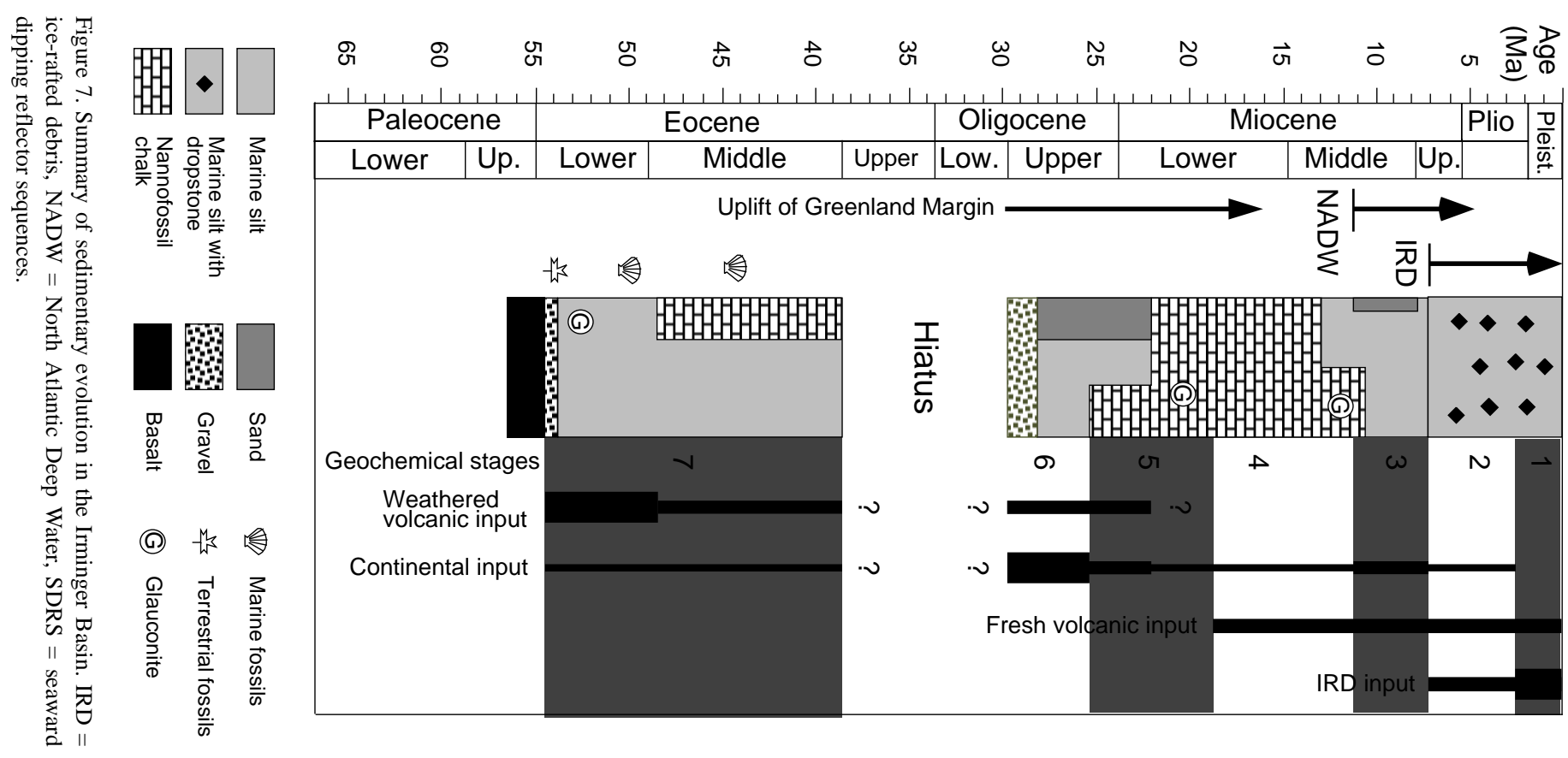

APPENDIX

Analytical Chemical Data from Site 918

\begin{tabular}{|c|c|c|c|c|c|c|c|c|c|c|c|c|c|c|c|c|c|c|c|c|c|c|c|}
\hline Hole: & $918 \mathrm{~A}$ & $918 \mathrm{~A}$ & $918 \mathrm{~A}$ & $918 \mathrm{~A}$ & $918 \mathrm{~A}$ & $918 \mathrm{~A}$ & $918 \mathrm{~A}$ & $918 \mathrm{~A}$ & $918 \mathrm{~A}$ & $918 \mathrm{~A}$ & $918 \mathrm{~A}$ & $918 \mathrm{~A}$ & $918 \mathrm{~A}$ & $918 \mathrm{~A}$ & $918 \mathrm{~A}$ & $918 \mathrm{~A}$ & $918 \mathrm{~A}$ & $918 \mathrm{~A}$ & $918 \mathrm{~A}$ & $918 \mathrm{~A}$ & $918 \mathrm{~A}$ & $918 \mathrm{~A}$ & $918 \mathrm{~A}$ \\
\hline Core, section: & $2 \mathrm{H}-1$ & $2 \mathrm{H}-4$ & $4 \mathrm{H}-2$ & $4 \mathrm{H}-4$ & $7 \mathrm{H}-2$ & $8 \mathrm{H}-1$ & $8 \mathrm{H}-7$ & $10 \mathrm{H}-2$ & $11 \mathrm{H}-6$ & $12 \mathrm{H}-5$ & $13 \mathrm{H}-5$ & $14 \mathrm{H}-2$ & $16 \mathrm{H}-2$ & $17 \mathrm{H}-3$ & $18 \mathrm{H}-3$ & $19 \mathrm{H}-5$ & $24 \mathrm{X}-1$ & $25 \mathrm{X}-3$ & $27 \mathrm{X}-6$ & $28 \mathrm{X}-3$ & $31 \mathrm{X}-3$ & $33 \mathrm{X}-2$ & $37 X-5$ \\
\hline Interval $(\mathrm{cm})$ : & $136-138$ & $6-8$ & 104-106 & $9-11$ & 92-94 & $128-130$ & $17-19$ & $3-5$ & $115-117$ & $63-65$ & $63-65$ & $142-144$ & 107-109 & $102-104$ & $122-125$ & $83-85$ & $2-4$ & $37-39$ & $13-15$ & $7-9$ & $45-47$ & $17-19$ & $62-64$ \\
\hline Depth (mbsf): & 3.16 & 6.36 & 23.34 & 25.39 & 51.72 & 60.08 & 67.97 & 79.33 & 95.95 & 103.43 & 112.93 & 118.72 & 135.87 & 146.82 & 156.52 & 168.63 & 217.62 & 226.9 & 251.73 & 255.87 & 282.95 & 298.97 & 330.52 \\
\hline \multicolumn{24}{|c|}{ Major elements (wt\%) } \\
\hline $\mathrm{SiO}_{2}$ & 66.93 & 54.38 & 69.68 & 69.45 & 67.94 & 56.39 & 65.89 & 64.24 & 71.39 & 64.18 & 48.62 & 65.47 & 64.72 & 63.78 & 63.61 & 63.50 & 68.16 & 66.30 & 71.95 & 62.96 & 64.63 & 55.48 & 61.45 \\
\hline $\mathrm{TiO}_{2}$ & 0.98 & 3.03 & 0.80 & 0.62 & 0.79 & 2.36 & 1.01 & 1.81 & 0.69 & 0.98 & 1.24 & 0.95 & 1.16 & 1.61 & 0.96 & 0.96 & 1.16 & 1.22 & 0.53 & 1.71 & 1.52 & 2.15 & 2.05 \\
\hline $\mathrm{Al}_{2} \mathrm{O}_{3}$ & 14.23 & 26.97 & 14.00 & 14.66 & 14.51 & 13.98 & 15.13 & 11.76 & 13.37 & 15.78 & 16.86 & 14.57 & 14.30 & 13.50 & 15.89 & 15.57 & 13.88 & 13.66 & 14.29 & 14.62 & 13.53 & 14.17 & 13.02 \\
\hline $\mathrm{Fe}_{2} \mathrm{O}_{3}$ & 6.29 & 9.62 & 5.11 & 4.64 & 5.33 & 11.40 & 6.99 & 10.12 & 4.85 & 7.13 & 12.56 & 7.31 & 7.22 & 9.04 & 7.35 & 7.18 & 7.01 & 6.81 & 3.70 & 9.45 & 7.90 & 12.19 & 9.80 \\
\hline $\mathrm{MnO}$ & 0.08 & 0.07 & 0.08 & 0.07 & 0.07 & 0.15 & 0.09 & 0.11 & 0.07 & 0.08 & 0.14 & 0.08 & 0.11 & 0.10 & 0.08 & 0.09 & 0.07 & 0.09 & 0.06 & 0.10 & 0.10 & 0.14 & 0.12 \\
\hline $\mathrm{MgO}$ & 2.40 & 1.66 & 2.06 & 1.93 & 2.10 & 4.44 & 2.61 & 3.43 & 1.80 & 2.88 & 8.06 & 2.67 & 2.78 & 3.49 & 3.02 & 3.14 & 2.49 & 2.90 & 1.55 & 3.05 & 3.23 & 4.79 & 3.83 \\
\hline $\mathrm{CaO}$ & 4.84 & 0.83 & 4.88 & 4.72 & 4.84 & 8.24 & 5.59 & 5.72 & 4.28 & 4.51 & 10.44 & 4.89 & 5.60 & 5.21 & 4.63 & 4.85 & 3.59 & 5.53 & 4.34 & 4.90 & 5.86 & 8.11 & 6.66 \\
\hline $\mathrm{Na}_{2} \mathrm{O}$ & 2.63 & 0.70 & 2.97 & 3.09 & 2.95 & 1.94 & 2.93 & 1.80 & 2.76 & 2.81 & 1.56 & 2.70 & 2.79 & 1.59 & 2.80 & 2.83 & 1.98 & 2.48 & 3.20 & 1.80 & 2.31 & 1.84 & 1.97 \\
\hline $\mathrm{K}_{2} \mathrm{O}$ & 1.36 & 1.56 & 1.14 & 1.23 & 1.24 & 0.90 & 1.21 & 1.28 & 1.16 & 1.71 & 0.27 & 1.48 & 1.21 & 1.49 & 1.77 & 1.80 & 1.9 & 1.23 & 1.18 & 1.49 & 1.24 & 0.89 & 1.12 \\
\hline $\mathrm{P}_{2} \mathrm{O}_{5}$ & 0.19 & 0.14 & 0.14 & 0.17 & 0.18 & 0.74 & 0.21 & 0.17 & 0.15 & 0.19 & 0.08 & 0.20 & 0.23 & 0.19 & 0.20 & 0.20 & 0.16 & 0.16 & 0.15 & 0.21 & 0.17 & 0.22 & 0.17 \\
\hline Total & 99.93 & 98.97 & 100.86 & 100.57 & 99.95 & 100.55 & 101.67 & 100.44 & 100.52 & 100.24 & 99.86 & 100.32 & 100.13 & 100.01 & 100.30 & 100.12 & 100.42 & 100.39 & 100.94 & 100.29 & 100.49 & 99.97 & 100.20 \\
\hline $\mathrm{H}_{2} \mathrm{O}^{-}$ & 0.78 & 2.73 & 0.69 & 0.51 & 0.53 & 1.41 & 0.68 & 0.99 & 0.44 & 0.94 & 1.61 & 0.96 & 0.33 & 1.21 & 0.86 & 0.69 & 1.13 & 0.59 & 0.24 & 2.39 & 0.75 & 1.25 & 1.11 \\
\hline LOI & 1.34 & 9.63 & 1.37 & 0.99 & 0.98 & 1.86 & 1.38 & 1.83 & 0.79 & 1.76 & 2.89 & 1.72 & 0.54 & 2.30 & 2.13 & 1.37 & 2.91 & 0.96 & 0.60 & 3.83 & 1.40 & 2.21 & 1.76 \\
\hline \multirow{2}{*}{\multicolumn{24}{|c|}{ Trace elements (ppm) }} \\
\hline & & & & & & & & & & & 10.81 & 38.33 & 46.82 & 41.58 & 60.27 & 55.20 & 57.84 & 23.22 & 41.41 & 50.00 & 33.31 & 25.42 & 32.14 \\
\hline $\mathrm{Sr}$ & 387.01 & 417.93 & 428.03 & 460.40 & 443.43 & 334.75 & 408.23 & 228.68 & 420.02 & 386.49 & 244.57 & 358.69 & 427.76 & 320.99 & 386.14 & 378.99 & 314.66 & 269.54 & 251.47 & 245.71 & 297.36 & 211.28 & 232.52 \\
\hline $\mathrm{Zr}$ & 260.08 & 455.88 & 294.05 & 165.92 & 276.95 & 251.13 & 270.29 & 230.35 & 258.04 & 219.07 & 143.75 & 164.01 & 240.99 & 260.44 & 208.38 & 230.01 & 153.59 & 202.25 & 209.70 & 197.20 & 222.31 & 183.98 & 231.14 \\
\hline $\mathrm{Nb}$ & 8.47 & 7.31 & 6.86 & 5.36 & 7.27 & 10.33 & 8.48 & 11.75 & 6.19 & 8.61 & 12.43 & 8.01 & 7.431 & 1.76 & 8.36 & 8.74 & 10.83 & 16.80 & 12.06 & 15.21 & 12.05 & 16.22 & 15.03 \\
\hline $\mathrm{Y}$ & 18.49 & 16.67 & 15.97 & 14.25 & 17.71 & 18.72 & 20.11 & 21.06 & 14.84 & 17.68 & 29.94 & 17.03 & 18.30 & 22.15 & 17.65 & 18.31 & 18.67 & 28.50 & 21.77 & 25.84 & 20.99 & 29.67 & 22.78 \\
\hline Th & 3.99 & 3.66 & 3.51 & 2.95 & 4.21 & 3.42 & 3.38 & 2.98 & 3.82 & 6.19 & 1.63 & 3.14 & 5.32 & 4.91 & 6.13 & 6.47 & & 2.61 & 3.45 & 5.25 & 3.05 & & 2.7 \\
\hline $\mathrm{Pb}$ & 9.25 & 8.66 & 9.12 & 9.42 & 10.29 & 6.98 & 9.77 & 4.96 & 8.87 & 9.94 & 0.54 & 8.52 & 9.97 & 9.04 & 9.52 & 9.51 & 11. & 3.29 & & & & 4.77 & 5. \\
\hline $\mathrm{Ni}$ & 33.99 & 24.15 & 27.56 & 28.64 & 28.53 & 36.25 & 33.78 & 45.18 & 23.69 & 47.56 & 46.48 & 38.42 & 35.68 & 31.56 & 46.41 & 47.72 & 56.06 & 46.19 & 42.06 & 36.55 & 38.54 & 49.20 & 43.91 \\
\hline $\mathrm{Ba}$ & 481.67 & 406.87 & 482.58 & 555.21 & 440.99 & 385.44 & 448.36 & 287.10 & 435.55 & 565.60 & 111.32 & 437.72 & 526.42 & 412.75 & 566.44 & 630.56 & 474.87 & 206.13 & 312.24 & 304.61 & 328.52 & 177.96 & 275.54 \\
\hline
\end{tabular}




\begin{tabular}{|c|c|c|c|c|c|c|c|c|c|c|c|c|c|c|c|c|c|c|c|c|c|c|c|}
\hline Hole: & 918D & 918D & 918D & 918D & 918D & 918D & 918D & 918D & 918D & 918D & 918D & 918D & 918D & 918D & 918D & 918D & 918D & 918D & 918D & 918D & $918 \mathrm{D}$ & 918D & 918D \\
\hline Core, section: & $18 \mathrm{R}-1$ & $22 \mathrm{R}-3$ & $25 \mathrm{R}-4$ & $28 \mathrm{R}-2$ & $31 \mathrm{R}-1$ & $32 \mathrm{R}-1$ & $33 \mathrm{R}-1$ & $34 \mathrm{R}-1$ & $35 \mathrm{R}-2$ & $36 \mathrm{R}-1$ & $37 \mathrm{R}-1$ & $38 \mathrm{R}-4$ & $39 \mathrm{R}-1$ & $40 \mathrm{R}-4$ & $41 \mathrm{R}-4$ & $42 \mathrm{R}-3$ & $44 \mathrm{R}-1$ & $47 \mathrm{R}-2$ & $51 \mathrm{R}-5$ & $52 \mathrm{R}-5$ & $53 \mathrm{R}-3$ & $55 \mathrm{R}-3$ & $57 \mathrm{R}-3$ \\
\hline Interval $(\mathrm{cm})$ : & $24-26$ & $4-6$ & $11-13$ & $25-27$ & $97-100$ & $133-136$ & $48-51$ & $15-16$ & $20-22$ & $21-24$ & $46-49$ & $31-34$ & $0-3$ & $133-135$ & $148-150$ & $32-35$ & $114-117$ & $138-140$ & $147-150$ & $1-4$ & $57-59$ & $69-71$ & $114-116$ \\
\hline Depth (mbsf): & 448.44 & 486.84 & 517.41 & 543.55 & 571.67 & 581.63 & 590.48 & 599.75 & 610.9 & 619.11 & 629.06 & 643.01 & 647.96 & 63.33 & 673.18 & 680.12 & 697.24 & 727.48 & 770.67 & 778.91 & 786.07 & 805.49 & 825.14 \\
\hline \multirow{2}{*}{\multicolumn{24}{|c|}{ Major elements (wt \%) }} \\
\hline & 64.40 & & & & & & & & & & 58.72 & 63.99 & 55.39 & 64.64 & 60.82 & 63.00 & 63.79 & 61.56 & 59.85 & 62.29 & 61.05 & 60.91 & 70.97 \\
\hline & 1.19 & 1.86 & 2.84 & 1.42 & 2.31 & 1.70 & 1.69 & 1.80 & 1.48 & 1.84 & 1.90 & 1.84 & 2.51 & 1.91 & 2.26 & 2.04 & & & 2. & 1.93 & 1.98 & 2.03 & 1.24 \\
\hline & 14.64 & 14.57 & 13.99 & 14.93 & 16.05 & 13.63 & 14.43 & 11.96 & 11.21 & 13.58 & 17.45 & 14.53 & 14.12 & 14.78 & 16.07 & 13.70 & 14.71 & 14.67 & 14.2 & 15.10 & 15.06 & 14.52 & 12. \\
\hline & 7.98 & 10.04 & 19.16 & 8.77 & 12.12 & 8.4 & 9.0 & 8.51 & 7.16 & 9.94 & 10. & 10.17 & 12. & 9 & 11. & 11. & 10. & 11 & 12. & 11. & 10. & 10.70 & \\
\hline & 0.08 & 0.10 & 0.10 & 0.07 & 0.09 & & & 0.0 & 0.05 & 0. & 0. & 0.0 & 0. & & & 0.0 & & & & & & & \\
\hline $\mathrm{MgO}$ & & & & & & & & 2.98 & 1.92 & & & & & 2.91 & & 3.09 & & & & & & & \\
\hline & & & & & & & & 2.72 & & & & & & & & & 3.83 & 4.52 & & & 4.16 & 4.29 & \\
\hline $\mathrm{a}_{2} \mathrm{O}$ & & & & 1. & & & & 1.31 & & & & 1.10 & & & & 1.15 & & & & & & 1.06 & \\
\hline $\mathrm{K}$ & 1.52 & 1.77 & 2.54 & 2.40 & 1.91 & 2. & 2. & 2. & 1.85 & 2.19 & 2.25 & 2.13 & 1.14 & 1.77 & 1.59 & 1.58 & 1.6 & 1.34 & 1. & & 2.02 & 2.04 & 1.59 \\
\hline $\mathrm{P}_{2} \mathrm{O}_{5}$ & 0.20 & 0.17 & 0.35 & 0. & & 0.12 & 0.15 & 0 & 0.11 & 0.15 & 0.17 & 0.16 & 0.28 & 0.13 & 0.13 & 0.13 & 0.19 & 0.22 & 0.16 & 0.22 & 0.91 & 0.35 & 0.09 \\
\hline & 99.55 & 99.80 & 98.64 & 100.55 & 99.92 & 100.39 & 99.70 & 100.03 & 100.16 & 99.63 & 99.96 & 99.94 & 100.15 & 100.40 & 99.99 & 100.30 & 99.77 & 100.34 & 98.16 & 100.40 & 100.08 & 99.34 & 100. \\
\hline & 1.26 & 1.4 & 5.41 & 1.19 & 2.3 & 1.4 & 1.91 & 1.39 & 1.30 & 1. & & 1.90 & 1.58 & 2.15 & 1.7 & 1.81 & & 2 & & 4. 48 & 3.84 & 48 & 1.43 \\
\hline LOI & 2.16 & 2.68 & 5.44 & 2.96 & 3.89 & 3.53 & 3.47 & 2.28 & 2.64 & 3.47 & 4.59 & 4.45 & 2.44 & 4.24 & 5.05 & 4.70 & 6.23 & 4.73 & 6.75 & 5.28 & 5.44 & 6.00 & 2.05 \\
\hline \multicolumn{24}{|c|}{ 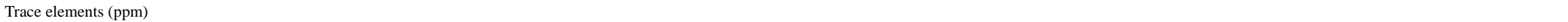 } \\
\hline & 2.19 & 59.44 & 101.92 & 91.22 & 61.79 & & 79.18 & 66.61 & 59.51 & 68.69 & & & & & & & & & & & & & \\
\hline S & 3 & 235. & & 210. & 9 & & & & 187. & & & 414 & & 2 & & & & & & & & & \\
\hline Z & 184.8 & 232.5 & 219. & 273. & & 300 & 291 & 339. & 392. & 299 & 211 & 227 & 207 & 237 & & & 158 & & & & 147 & & \\
\hline $\mathrm{N}$ & & & & & & & & & & & & & & & & & & & & & & & \\
\hline$Y$ & & & & & & & & & & & & & & & & & & & & & & & \\
\hline $\mathrm{T}$ & & & & & & & & & & & & & & & & & & & & & & & \\
\hline & & & & & & & & & & & & & & & & & & & & & & & 8 \\
\hline $\mathrm{Ni}$ & 48.47 & 54.39 & 39.50 & 48.70 & 75.86 & 44.88 & 47.83 & 44.37 & 37.41 & 55 & 68.99 & 41.93 & 39.97 & 45.67 & 66.80 & 73.48 & 38.52 & 49.86 & 63.34 & 42.79 & 42.68 & 27.94 & 55.61 \\
\hline $\mathrm{Ba}$ & 447.59 & 323.47 & 432.31 & 419.15 & 297.98 & 361.72 & 347.67 & 374.35 & 414.13 & 341.19 & 347.28 & 387.88 & 410.38 & 387.04 & 322.71 & 334.53 & 497.71 & 352.61 & 524.32 & 468.78 & 528.71 & 317.91 & 488.43 \\
\hline
\end{tabular}

\section{APPENDIX (continued).}

Hole:

$\begin{array}{llllllllllllllllllllllll}\text { 918D } & 918 \mathrm{D} & 918 \mathrm{D} & 918 \mathrm{D} & 918 \mathrm{D} & 918 \mathrm{D} & 918 \mathrm{D} & 918 \mathrm{D} & 918 \mathrm{D} & 918 \mathrm{D} & 918 \mathrm{D} & 918 \mathrm{D} & 918 \mathrm{D} & 918 \mathrm{D} & 918 \mathrm{D} & 918 \mathrm{D} & 918 \mathrm{D} & 918 \mathrm{D} & 918 \mathrm{D} & 918 \mathrm{D} & 918 \mathrm{D} & 918 \mathrm{D} & 918 \mathrm{D} & 918 \mathrm{D} \\ \text { 58R-1 } & 60 \mathrm{R}-1 & 62 \mathrm{R}-2 & 63 \mathrm{R}-2 & 68 \mathrm{R}-1 & 72 \mathrm{R}-1 & 74 \mathrm{R}-1 & 75 \mathrm{R}-4 & 76 \mathrm{R}-1 & 77 \mathrm{R}-1 & 78 \mathrm{R}-1 & 79 \mathrm{R}-1 & 80 \mathrm{R}-1 & 83 \mathrm{R}-1 & 84 \mathrm{R}-1 & 86 \mathrm{R}-1 & 89 \mathrm{R}-1 & 90 \mathrm{R}-3 & 91 \mathrm{R}-1 & 92 \mathrm{R}-1 & 95 \mathrm{R}-2 & 96 \mathrm{R}-3 & 99 \mathrm{R}-3 & \text { 100R-2 }\end{array}$ Core, section:
Interval $(\mathrm{cm})$ Depth (mbsf):

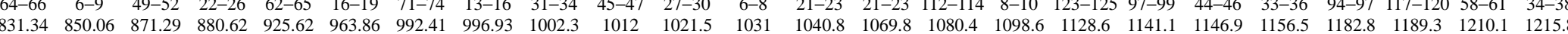

\begin{tabular}{|c|c|c|c|c|c|c|c|c|c|c|c|c|c|c|c|c|c|c|c|c|c|c|c|c|}
\hline \multicolumn{25}{|c|}{$(w t \%)$} \\
\hline $\mathrm{SiO}_{2}$ & 73.59 & 59.45 & 56.50 & 62.63 & 72.86 & 57.66 & 59.73 & 72.32 & 70.50 & 78.92 & 63.68 & 53.28 & 77.31 & 75.16 & 75.01 & 76.24 & 63.67 & 52.73 & 60.70 & 62.17 & 68.62 & 62.08 & 48.61 & 53.42 \\
\hline $\mathrm{TiO}$ & 0.90 & 2.15 & 2.62 & 2.44 & 0.97 & 2.73 & 2.07 & 1.13 & 1.33 & 0.68 & 1.61 & 2.58 & 0.68 & 0.73 & 0.97 & 0.71 & & 1.81 & 2.09 & & & & & \\
\hline $\mathrm{Al}_{2} \mathrm{O}_{3}$ & 11.87 & 12.39 & $\begin{array}{l}11.45 \\
\end{array}$ & 13.28 & 10.94 & 11.92 & 12.96 & 11.12 & 11.86 & 9.59 & 12.38 & 18.99 & $\begin{array}{l}0.09 \\
10.09\end{array}$ & 10.82 & 10.31 & 11.33 & 15.57 & $\begin{array}{l}18.02 \\
18.02\end{array}$ & 17.18 & $\begin{array}{l}15.12 \\
1.12\end{array}$ & 6.07 & 11.10 & 18. & 17.51 \\
\hline $\begin{array}{l}\mathrm{H}_{2} \mathrm{O}_{3} \\
\mathrm{Fe}\end{array}$ & $\begin{array}{r}5.00 \\
5.00\end{array}$ & 13.41 & $\begin{array}{l}1.45 \\
15.27\end{array}$ & 10.43 & $\begin{array}{r}6.53 \\
\end{array}$ & 14.49 & 12.59 & 6.86 & 7.88 & 4.42 & 8.75 & 15.16 & 5.15 & 5.64 & 6.75 & 4.96 & 8.37 & 12.35 & 12.34 & 13.28 & 16.89 & 17.17 & 16.31 & 19.88 \\
\hline $\mathrm{MnO}$ & 0.05 & 0.05 & 0.05 & 0.05 & 0.03 & 0.06 & 0.04 & 0.04 & 0.05 & 0.03 & 0.05 & 0.07 & 0.03 & 0.03 & 0.04 & 0.04 & 0.07 & 0.04 & 0.02 & 0.04 & 0.04 & 0.04 & & 0.09 \\
\hline $\mathrm{MgO}$ & 2.18 & 6.03 & 9.05 & 4.90 & 3.28 & 5.96 & 7.21 & 3.11 & 2.77 & 1.80 & 5.38 & 2.38 & 2.10 & 2.35 & 1.87 & 1.32 & 3.16 & 2.96 & 3.43 & 4.11 & 2.87 & 2.69 & $\begin{array}{l}6.119 \\
6.39\end{array}$ & 3.07 \\
\hline $\mathrm{CaO}$ & 3.09 & 2.81 & 2.70 & & 1.83 & 1.75 & 1.96 & 2.08 & 2.25 & 1.82 & 2.91 & 1.59 & 1.67 & 1.66 & 1.72 & 2.06 & 2.71 & 6.00 & 1.76 & 1.43 & 0.60 & 0.80 & 5.06 & 1.19 \\
\hline & 2.21 & 1.45 & 0.66 & 1.46 & 1.65 & 0.57 & 0.63 & 1.47 & 1.33 & 1.71 & 1.44 & 1.55 & 1.71 & 1.69 & 1.63 & 2.07 & 1.50 & 0.32 & 0.29 & 0.35 & 0.14 & 0.54 & 1.54 & 0.15 \\
\hline & 1.54 & 1.96 & 1.64 & 2.17 & 1.92 & 3.58 & 2.55 & 2.02 & 2.21 & 1.60 & 2.49 & 2.71 & 1.97 & 2.01 & 1.97 & 2.00 & 2.81 & 1.69 & 1.73 & 1.65 & 3.98 & 2.83 & 0.34 & 1.62 \\
\hline & 0.06 & 0.30 & 0.21 & 0.16 & 0.08 & 0.25 & 0.26 & 0.12 & 0.19 & 0.05 & 0.96 & 0.11 & 0.07 & 0.08 & 0.0 & 0.07 & 0.17 & 2.9 & 0.20 & 0.12 & 0. & 0.06 & & 0.03 \\
\hline Total & 100.50 & 100.00 & 100.15 & 100.08 & 100.08 & 98.96 & 99.99 & 100.26 & 100.37 & 100.62 & 99.65 & 98.42 & 100.77 & 100.17 & 100.31 & 100.79 & 99.38 & 98. & 99.74 & 99.97 & 99. & 98. & & 98.35 \\
\hline $\mathrm{H}_{2} \mathrm{O}$ & $\begin{array}{l}0.72 \\
0.72\end{array}$ & 3.48 & 5.51 & $\begin{array}{l}100.08 \\
1.98\end{array}$ & 1.11 & $\begin{array}{r}0.90 \\
3.93\end{array}$ & 3.97 & $\begin{array}{l}100.60 \\
1.61\end{array}$ & 3.57 & 0.93 & 2.30 & $\begin{array}{r}0.42 \\
2.27\end{array}$ & 0.54 & $\begin{array}{r}100.17 \\
1.49\end{array}$ & 0.96 & 0.67 & 1.77 & & 4.7 & & 1. & & & $\begin{array}{r}7.53 \\
7.09\end{array}$ \\
\hline LOI & 1.15 & $\begin{array}{l}3.46 \\
3.72\end{array}$ & 4.65 & $\begin{array}{l}3.19 \\
\text {. }\end{array}$ & 1.96 & 4.68 & 5.01 & $\begin{array}{l}2.01 \\
2.49\end{array}$ & 2.99 & 1.30 & 3.05 & 2.34 & $\begin{array}{l}0.63 \\
1.63\end{array}$ & 1.90 & $\begin{array}{l}1.85 \\
1.85\end{array}$ & $\begin{array}{l}.01 \\
1.45\end{array}$ & 3.11 & 9.18 & 8.04 & $\begin{array}{l}6.180 \\
6.18\end{array}$ & 4.17 & $\begin{array}{l}4.67 \\
\end{array}$ & 3.53 & 6.29 \\
\hline \multicolumn{25}{|c|}{ Trace elements (ppm) } \\
\hline $\mathrm{Rb}$ & 37.10 & & & & 38.26 & & 30.98 & 32.35 & 31.32 & & 37.16 & 41.77 & 37.94 & 39.05 & 45.07 & 46.52 & 39.05 & 30.14 & 4255 & 5116 & 128.17 & 9923 & & 2665 \\
\hline S & & 386.64 & 424.99 & 321.47 & 248.19 & 6.21 & 434.41 & 327.81 & 421.89 & & 212.60 & 220.19 & 221.55 & 230.63 & 237 & 286.82 & & & 252 & & & & & 57.83 \\
\hline & 3.37 & 181.74 & 149.13 & $26 \mathrm{C}$ & 144.1 & 211. & 174. & 151. & 167. & 168.4 & 195 & 273. & 121.60 & 136. & 241 & 151. & 153. & 154 & 171 & 143. & & 148 & 62. & 52.16 \\
\hline & & & & & 10. & & & 10 & & & & 19 & & & 11. & 7. & & 12 & & 10. & & & & 0.97 \\
\hline & & & & & & & & 12. & 14. & & 35 & 19. & & & & & 19. & 90. & & 15. & & 13.1 & & 9.94 \\
\hline & & & & & & & & & & & & 4. & 1.8 & 2. & 4. & 3 & & & & & & & 0.24 & 0.37 \\
\hline & & 6.14 & 5.8 & 6.8 & 5.6 & 15.31 & 8. & 7.36 & 6. & 6.11 & 7.6 & 8.78 & 7.1 & 5.87 & 11.14 & 12.79 & 9.8 & 5.28 & 4.8 & 5.20 & 1.38 & 2.74 & 0.18 & 0.42 \\
\hline $\mathrm{Ni}$ & 35.52 & 62.67 & $\begin{array}{r}55.05 \\
\end{array}$ & 53.31 & 38.19 & 79.93 & 46.51 & 43.15 & 43.10 & 30.24 & 78.74 & 52.58 & 34.75 & 39.52 & 42.68 & 31.68 & 69.24 & 97.25 & 84.05 & 241.74 & 58.73 & 148.08 & 90.83 & 52.62 \\
\hline $\mathrm{Ba}$ & 547.23 & 246.14 & $\begin{array}{r}188.20 \\
\end{array}$ & 364.93 & 478.34 & 215.80 & 274.53 & 387.89 & 289.87 & $\begin{array}{r}30.24 \\
462.33\end{array}$ & 332.06 & 477.96 & 425.34 & 477.31 & 475.31 & $\begin{array}{r}600.19 \\
\end{array}$ & $\begin{array}{r}09.24 \\
196.50\end{array}$ & 1404.80 & $\begin{array}{r}0 \\
163.05\end{array}$ & 757.92 & 100.61 & $\begin{array}{l}140.00 \\
174.67\end{array}$ & 24.05 & 37.40 \\
\hline
\end{tabular}

